Article

\title{
The Role of Language Policy Documents in the Internationalisation of Multilingual Higher Education: An Exploratory Corpus-Based Study
}

\author{
Rosana Villares $(\mathbb{D}$ \\ Department of English and German Studies, University of Zaragoza, 50009 Zaragoza, Spain; \\ rosanavillares92@gmail.com
}

Received: 13 May 2019; Accepted: 11 July 2019; Published: 15 July 2019

\begin{abstract}
Using corpus methods, this study explores the role of Language Policy (LP) documents in the internationalisation process of Spanish universities. It aims at understanding how non-Anglophone universities integrate English and local languages in the functions of education, research, and administration. Content analysis was used for the identification of key themes, and discourse analysis examined how those themes were textually expressed. Consistent with previous literature, this study shows that relevant strategic areas of LP deal with training, regulation, accreditation, and support measures. Results also highlight the role played by institutions in LP and the presence of language hierarchies between English and local languages. The discussion of these findings leads to further inquiry of mismatches between top-down institutional expectations and bottom-up realities regarding the design and implementation of institutional policies.
\end{abstract}

Keywords: language policy; higher education; internationalisation; discourse analysis; language diversity; language attitudes; English linguistic imperialism; Spanish universities

\section{Introduction}

Over the last decades, internationalisation, regarded as an indicator of excellence and quality, has become one of the main strategic objectives of universities worldwide (EHEA 2015; Maringe and Foskett 2010). Following European recommendations (European Commission 2010, 2013), the national strategy for the internationalisation of Spanish universities 2015-2020 (MECD 2014) is based on four main pillars: The consolidation of a strong national university system, the increase of the international attractiveness of the university system, the creation of international competitive universities, and the promotion of cooperation with other regions of the world (MECD 2014). The actions proposed to achieve these objectives tend to focus on mobility, international collaboration, and the development of language-related initiatives, such as the implementation of English-medium instruction (EMI) that foster the international and multilingual profile of universities (Wächter and Maiworm 2014).

Ferguson (2010) or Hultgren (2014), among others, have noted that there is a direct correlation between internationalisation and the use of English, which is considered to be the academic lingua franca for international communication. This hegemonic position of English is also supported by the concept of language hierarchy that classifies languages according to a series of given values and functions. Within this hierarchy, English holds the position of a 'hypercentral' language, thus becoming a global lingua franca (de Swaan 2001). This situation is encountered in many contexts, yet the Spanish sociolinguistic landscape presents some special characteristics. On the one hand, Spanish as the national official language holds the status of an international language with Spanish-speaking Latin American countries that works as an attractive factor for those interested in the Spanish culture and language (MECD 2014; SEPIE 2017). On the other hand, regional co-official languages are promoted 
in universities located in bilingual regions. Thus, the introduction of a powerful foreign language brings certain challenges that are generally addressed in Language Policy documents (LP), tools whose purpose is the regulation of languages in specific contexts and domains (Spolsky 2012). Currently, it is possible to track multiple studies on students and academics' language practices and beliefs towards English and multilingualism in universities (e.g., Fortanet-Gómez 2012; Hultgren 2014; Pérez-Llantada 2018; Soler-Carbonell and Karaoglu 2015), but, to the best of my knowledge, there seems to be a lack of critical studies on the role held by policy documents regulating language(s) use in the Spanish national context.

This paper aims to explore how non-Anglophone universities integrate English and the local languages in their LP documents to become more internationalised and to match bottom-up practices. For this task, the following research questions will be addressed:

RQ1 Do LP documents share similar language concerns to those stated in the national LP (CRUE 2017)? $\mathrm{RQ} 2$ What is the role played by institutional agents in the implementation of LP?

RQ3 How is the relationship between English and the local languages discursively expressed?

\section{Methodology}

The corpus compiled for this study included 37 institutional LP documents created between 2001 and 2018 from 29 Spanish universities. Depending on the origin of the LP, the documents were written in Spanish or in the co-official language of the region-Catalan, Valencian, or Galician. Several analytical approaches were used to analyse the documents following Bocanegra-Valle (2017). Content analysis and inductive coding were carried out using the qualitative software Atlas.ti v8 to identify key themes and strategic areas in the LP documents. Discourse analytical techniques were used to examine the way institutional actors presented themselves, their roles and responsibilities in the creation of LP, and the discursive strategies the authors of these documents used to align with their readers' opinions. Lastly, a comparative analysis was carried out to describe the English language in contrast to the local languages.

\section{Results}

\subsection{Strategic Actions}

Similar to the recommendations included in the Spanish national LP created for higher education (CRUE 2017), the corpus findings pointed out to the following strategic areas as recurrent concerns in LP: Language training, language regulation, language accreditation, and support measures. It was found that the majority of the strategies were related to the dimension of training and aimed at increasing university members' language competence by means of language courses and innovative methodologies - the latter addressed to the teaching staff so they could acquire teaching techniques that adapt contents and communicative styles when teaching in a foreign language. Other initiatives referred to the possibility to participate in extra-curricular activities that promoted language learning outside the classroom. International trends, such as those stated by Wächter and Maiworm (2014), were also present in the form of modules taught in a foreign language or co-official language in undergraduate and graduate degrees.

From the content analysis, it became evident that there was a common agreement on the need to regulate language use, especially in those areas where more than one language could compete for the same functions. LP was described as the most suitable tool to organise and regulate language choice and language use, a tool also fostered by European institutions to promote multilingualism and internationalisation (European Commission 2012). References to language regulation highlighted the recurrent concept of 'linguistic security', which referred to both the LP's general objective of communicating the language initiatives taking place at the university, as well as the specific objective of informing university members about language use in particular settings. For example, in the case of 
EMI courses and bilingual teaching programs, information regarding the vehicular language used in the classroom should be available to students before the enrolment period.

The third dimension dealt with the accreditation of language competence (CRUE 2017; European Commission 2012). The corpus results established a direct relationship between accreditation, language competence, and language requirements. The required language level changed depending on the initiative's purpose and target group. For example, undergraduate students were expected to acquire at least a B1 level for graduation, teaching staff who wanted to participate in EMI courses a B2-C1 level, students who wished to learn by means of bilingual degrees needed at least a B2 level for enrolment, and administrative staff working in areas related to international relations or seeking a job promotion needed a B2 level of English and/or the co-official language of the region.

The last area concerned support measures. In the documents, these measures were considered essential in the implementation of university LP. The findings explicitly recognised the efforts of communicating in a second language made by the university staff (CRUE 2017; Pérez-Llantada 2018, p. 38). Support measures included both incentives-financial, job promotion, added value for participation in mobility programmes and courses-and the creation of language service units that offered online language resources, translation and proofreading services for academic writing, or the creation of teaching materials in a language different than the mother tongue.

\subsection{Institutional Agency}

\subsubsection{Accountability towards Languages}

It was observed that depending on each university's context, the LP objectives varied and favoured certain languages over others. For instance, there was a dichotomy between the goal to become international through the use of English and foreign languages and universities' interest in protecting local languages, which translated into the desire to give them a more predominant use in the university context. The following extracts suggest a protectionist view of languages associated with co-official languages, which creates a space for the local community in a globalised world.

1. Será o que entre todos e todas queiramos que sexa, exactamente igual que o futuro da lingua galega na nosa universidade (Universidade da Coruña 2006, Plano de normalización lingüística).

It will be whatever we, all of us, want it to be, exactly the same as the future of Galician in our university.

2. La UPV/EHU siempre ha mostrado una actitud claramente favorable al euskera, postura que este nuevo plan pretende mantener, en la línea del esfuerzo que la universidad lleva años realizando por lograr una universidad bilingüe (Universidad del País Vaso 2013, II Plan Director del Euskera de la UPV/EHU).

The university has always shown a clear positive attitude towards Basque, an attitude this new plan is expected to maintain, similar to the effort the university has been carrying out to become a bilingual university.

Generally, the university presents itself as the actor responsible for fostering the use of a specific language. In Example (1), the co-official language (Galician) is presented with inclusive possessive pronouns (nosa, 'our') and noun phrases (entre todos e todas, 'all of us (men and women)') to turn an institutional objective into the reader's objective through a sense of proximity and community. In the case of Example (2), a more explicit discourse is found in relation to the use of the co-official language (Basque). The university's voice is clearly identified in the document with the use of adverbs and attitude markers that state the importance of language objectives (actitud claramente favorable, 'a clearly positive attitude'; postura ... pretende mantener, 'attitude [it is] expected to maintain; esfuerzo ... lograr una universidad bilingüe, 'effort ... to become a bilingual university') and the current efforts undertaken by the university to normalise the use of such language in the local context. 
3. El entorno global en el que los futuros graduados deberán desarrollar sus carreras profesionales exige la familiarización con contenidos con carácter internacional y el dominio del inglés, actual lingua franca (Universidad de Navarra 2017, Bilingüismo en la universidad).

The global context in which future graduates must develop their professional careers demands the familiarisation with international contents and proficiency in English, the current lingua franca.

Example (3), on the other hand, illustrates how the institution must adapt to the external pressures of a globalised society, which means English should be introduced in the university context as a consequence of social demands and needs (actual lingua franca, 'current lingua franca') (Ferguson 2010; Hultgren 2014). This situation is reflected in the use of obligation verbs (exige, 'demands') and modal verbs (deberán, 'must') that identify universities as the entities responsible for providing the necessary tools to learn English, the taken-for-granted lingua franca of international communication.

\subsubsection{Prestige and Excellence}

The institution's role in LP was closely related to the desire to project an international prestigious image of the university. Prestige and excellence are two aspects that tend to be linked to internationalisation, and a way to achieve them is through the introduction of English and other languages in the university context (EHEA 2015; MECD 2014; SEPIE 2017).

4. La dilatada historia de la UGR, su reconocimiento como una universidad europea de prestigio y sus perspectivas de futuro exigen un enfoque constructivo hacia las lenguas y el plurilingüismo que las considere un importante recurso (Universidad de Granada 2017, Política lingüística).

The extensive history of the university, its recognition as a prestigious European university, and its long-term plans demand a constructive approach towards languages and plurilingualism that considers them an important resource.

In Example (4), the institution bases its argumentation on positive features to support the strategic objective of internationalisation (dilatada historia, 'extensive history'; reconocimiento ... universidad europea de prestigio, 'recognition as a prestigious European university'). In doing so, it also acknowledges the importance of languages in the process (exigen un enfoque ... hacia las lenguas y el plurilingualismo, 'demand an approach ... towards languages and plurilingualism'), which relates to Section 3.1 and the view of LP as a necessary tool for higher education institutions. The institution uses an authoritarian voice that creates a direct connection between prestige and languages.

5. Por tanto, la Universidad CEU San Pablo, consciente de que la apuesta por la calidad y la internacionalización exige dar pasos cada vez más firmes en la exigencia de competencias transversales a todos sus grados, establece el siguiente Reglamento que obliga a que todos sus estudiantes, [ ... ], acrediten un nivel mínimo de conocimientos y de competencias en lengua inglesa (CEU Universidad San Pablo 2017, Acreditación de nivel de inglés para la obtención de los títulos de grado)

The university CEU San Pablo is aware of the fact that quality and internationalisation demand sound steps to move forward, which requires the presence of transversal competences in all the degrees. Therefore, it establishes the following Regulation that makes it compulsory for all students [ ... ] to certify a minimum level of English competence and knowledge.

Similarly, Example (5) explicitly links the discourses of internationalisation and quality to English, which indicates that the three of them are tools that boost the excellence standards of the university (la calidad y la internacionalización exige ... competencias en lengua inglesa, 'quality and internationalisation that demand ... English competence and knowledge'). The establishment of language requirements also highlights one of the main areas of concern of LP in Spain, which is the accreditation of university stakeholders' language competence, as seen above in Section 3.1 and CRUE (2017). 
At the textual level, the exertion of top-down authority is often established by the use of obligation verbs (exige, exigencia, 'demands', 'makes compulsory') as well as the external social situation (perspectivas de futuro, 'long-term plans'; por lo tanto ... consciente de que la apuesta, 'therefore, [the university] is aware of ...' ').

\subsubsection{Institutional Authoritarian Voice}

A more thorough examination of the institution's voice shows the use of different discursive strategies to fulfil its demands for language skills. Authority is conveyed not only through the use of modal verbs and attitude markers, but also through the use of argumentation based on social practices, global demands, or aligning its objectives to external circumstances like supranational policies, national and regional regulation, or research studies. Institutional actions are consequently justified by the government's policies and experts' opinions.

An example of the latter strategy is seen in Example (6), which gives a sense of well-founded argumentation (de común acuerdo, 'of common agreement'; como queda reflejado, 'as it is said by'). This strategy was frequently found when languages were discussed in general, without explicitly addressing a specific language, giving more predominance to the expert's voice and reducing the institution's voice to a neutral stance.

6. Respecto al reto particular de la cualificación lingüística del profesorado es de común acuerdo, tal y como queda reflejado en la literatura científica, que el nivel mínimo exigible es un nivel C1 (Universidad de Salamanca 2016, Plan para la Internacionalización Lingüística).

Regarding the specific challenge of the teaching staff's language training, it is of common agreement that, as it is said by the literature, the minimum level that can be required is $\mathrm{C} 1$.

7. Eso, ni qué decir tiene, exige que el personal que atiende al público conozca tanto el euskera como el castellano (ibid. (2)).

That, without hesitation, demands that the staff who offer public-oriented services know both Basque and Spanish.

However, a different approach was used when references to a specific language appeared, especially in the case of co-official languages. For instance, in Example (7), the institution used a subjective position through the use of attitude markers (eso ni que decir tiene exige, 'that, without hesitation, demands ... ') that shows implications regarding language expectations-e.g., importance and obligation. This change of attitude could be linked to what was observed in Section 3.2.1, when the institution adopted an inclusive and protective stance towards local languages-e.g., Basque and Spanish in the case of Example (7).

\subsection{Languages in $L P$}

\subsubsection{Language Functions}

Lastly, a comparative analysis was carried out to describe the English language in contrast to the local languages. One of the objectives of LP is to identify and establish the functions of the different languages that co-exist in a specific context when a situation demands regulation of use. According to the documents analysed, languages perform several functions. The introduction of English in the local context has created two scenarios, either replacement or duplication of uses (Hultgren 2014). For example, Examples (8), (9), and (10) explicitly state the different statuses and functions that languages can hold in the university ('own language', 'official languages', 'lingua franca', 'working language'), whether granted by law-e.g., Catalan, Spanish—or by daily use in certain domains-English, other languages/foreign languages. Challenges appear though, in the case of languages whose presence has become expected in certain spheres, like English, but its implications are not clearly discussed (Pérez-Llantada 2018; Soler-Carbonell and Karaoglu 2015). 
8. La transparencia y la efectividad de los derechos y los deberes lingüísticos que se derivan del estatus de las lenguas: del catalán como lengua propia, del catalán y del castellano como lenguas oficiales, del inglés como lengua franca de la comunidad académica internacional, y también de otras lenguas en contextos específicos (Universitat Autònoma de Barcelona 2016, Plan de lenguas).

The transparency and effectiveness of language rights and duties result from the status of languages: Catalan as the own language, Catalan and Spanish as official languages, English as the lingua franca of the international academic community, and other languages in specific contexts too.

9. Reconoce el papel de la lengua inglesa como lingua franca académica internacional, lo que se refleja en la necesidad de regular de forma específica su estatus en nuestra institución (ibid. (4)).

It recognises the role of English as the international academic lingua franca, which is reflected in the need to regulate its status in a specific way within our institution.

10. Anglès com a llengua de treball o d'ús corrent a la Universitat Pompeu Fabra té una sèrie de conseqüències pràctiques i jurídiques (Universitat Pompeu Fabra 2007, Pla d'acció pel multilingüisme).

English as the common use or working language at the University Pompeu Fabra has a series of practical and legal consequences.

Several languages can be used when they fulfil a similar function, as seen in Example (11): English is used for international communication in the domain of research dissemination, while Catalan and Spanish are used for specific research purposes, which may be influenced by the research topic and target audience.

11. En les activitats de recerca i difusió, la UOC vol potenciar l'ús de la llengua anglesa com a principal vehicle d'intercanvi científic internacional, mantenint l'ús del català i l'espanyol per a la difusió de la recerca en contextos més específics (Universitat Oberta de Catalunya 2015, Princips generals de política lingüística).

In the activities of research and dissemination, the university wants to promote the use of English as the main vehicle of international scientific exchange, keeping the use of Catalan and Spanish for the dissemination of research in more specific contexts.

It can then be deduced that in this scenario, the functions of languages might be shaped by the geographical location of the target audience. Example (11) illustrates how the institutional protective view of local languages reflects concern towards the maintenance of local languages, especially in domains where English has become the predominant language choice. In general, universities (Examples (9), (10)) are aware of the need for regulation of the presence of English (en la necesidad de regular de forma explícita, 'need for explicit regulation'; conseqüències pràctiques i jurídiques, 'practical and legal consequences'), as seen in Section 3.1, but this also brings to the fore implications for policymakers, e.g., the extent to which it can be institutionalised and become an official working language of the university; or the language requirements that will be asked for depending on different purposes or stakeholders' needs.

\subsubsection{Language Hierarchies}

I ended the previous section with Example (11) that insinuated a certain level of resistance to the linguistic hegemony of English. This section specifically focuses on the way in which language attitudes are translated into the LP documents at a textual level, which on some occasions may favour English, and in others the local languages. This is generally expressed at the textual level with the use of attitude markers, adverbs, enumeration, coordination, disjunction, and so on.

12. A investigación realízase principalmente en castelán ou en inglés (ibid. (1)). 
Research should be done mainly in Spanish or English.

13. Enseñanza en las dos lenguas oficiales y la posibilidad de impartir en una lengua no oficial, preferentemente el inglés (Universitat d'Alacant 2013, Plan de política lingüística).

Teaching in the two official languages, and the possibility to teach in a non-official language, preferably English.

14. Hacer que el valenciano sea, de verdad, lengua de atención a los usuarios y de relación profesional [ ... ], y, en determinados puestos de trabajo, el inglés u otras lenguas no oficiales (ibid. (13)).

Making Valencian, really, the language used for communication with users and for professional relations [ ... ] and, in specific job positions, English or other non-official languages.

An analysis of these examples shows a balanced position of Spanish and English in the research field (Example (12)): 'In Spanish or in English'); in other cases (Examples (13) and (14)), local languages hold a privileged position as they are described as the preferred language choice (enseñanza en las dos lenguas oficiales, 'teaching in the two official languages'; hacer que el valenciaso sea, de verdad, lengua ... , 'make Valencian the real language of ... '). Despite relegating English to a second position in these two examples, it is still more valued than other foreign languages, which is marked with the use of adverbs (preferentemente, 'preferably') and the position in the disjunctive phrase 'English or other non-official languages' because its name is specified in contrast to the general noun phrase of 'non-official languages'. Therefore, it still maintains a privileged status, which shows language beliefs towards the practicality and benefits of English in comparison to other languages.

\section{Discussion and Concluding Remarks}

In this paper, I have examined how LP documents from Spanish universities convey language beliefs and regulate language practices. Regarding RQ1, the corpus findings indicated, as expected, that universities follow a similar line to the one established by the national LP framework (CRUE 2017), particularly in terms of training, regulation, accreditation, and support. From these areas, language training gains special attention in the form of, firstly, training staff and students so that they can communicate in at least two languages-mother tongue and another language - and secondly, the creation of language resources and real opportunities for (multilingual) language use.

Answers to RQ2 suggest that universities generally show positive attitudes towards languages. These beliefs and attitudes tend to shape LP objectives and rationales according to the institution's geographical and sociolinguistic context. Additionally, a desire is observed to promote language diversity (European Commission 2012; Fortanet-Gómez 2012), especially in the case of co-official languages and the introduction of English in the university domains of teaching and research. In doing so, while universities adopt a protectionist role regarding co-official language promotion, the introduction of English is regarded as a duty or responsibility. Thus, this supports the view that LP, as a regulatory tool, is essential when tensions might arise from the introduction of a new language in the local context.

As far as RQ3 is concerned, English is explicitly linked to the discourse of internationalisation and excellence, which justifies the introduction of English in a non-Anglophone context (Ferguson 2010; Hultgren 2014; Wächter and Maiworm 2014). Despite the general agreement that English is a necessary element of modern higher education, its presence is rather seen as a consequence of external circumstances whereas the references to co-official languages seem to come from an internal motivation of universities. This may explain the variation of discursive strategies found in relation to languages (Bocanegra-Valle 2017). While co-official languages present engaging and persuasive strategies, and Spanish is mentioned with a neutral stance, English is more likely to be found in relation to obligation, reflected in the use of modal verbs and intertextuality-external sources of argumentation.

To conclude, this paper is hoped to add new insights on the relevance of critical understanding of institutional documents to the field of LP and internationalisation in the Spanish context; these hold important implications for establishing the role languages should play in the modernisation of 
universities and academia, either involving the form of the monolingual advancement of English, or, what seems to be in line with current trends, the promotion of language diversity.

Funding: This research was supported by the Spanish Ministry of Economy and Competitiveness and the European Social Fund (project code: FFI2015-68638-R) and by the Regional Government of Aragón (project code: H16_17R).

Conflicts of Interest: The author declares no conflict of interest.

\section{References}

Bocanegra-Valle, Ana. 2017. Promotional Discourse at Internationalised Universities: A Critical Discourse Analysis Approach. Paper presented at 35th International Conference of the Spanish Society of Applied Linguistics, Jaén, Spain, May 4-6. Available online: https://genresandlanguages.org/wp-content/uploads/ 2018/03/2017.05.05_BocanegraValle_Promotional-discourse.pdf (accessed on 13 May 2019).

CRUE. 2017. Documento Marco de Política Lingüística para la Internacionalización del Sistema Universitario Español. Available online: https:/www.crue.org/Documentos\%20compartidos/Sectoriales/ Internacionalización\%20y\%20Coorperación/Marco_Final_Documento\%20de\%20Politica\%20Linguistica\% 20reducido.pdf (accessed on 13 May 2019).

de Swaan, A. 2001. Words of the World: The Global Language System. Cambridge: Polity Press and Blackwell.

EHEA (European Higher Education Area). 2015. The European Higher Education Area. Edited by Adrian Curaj, Liviu Matei, Remus Pricopie, Jamil Salmi and Peter Scott. Cham: Springer International Publishing. [CrossRef]

European Commission. 2010. Council Conclusions of 11 May 2010 on the Internationalisation of Higher Education. Available online: https:/eur-lex.europa.eu/LexUriServ/LexUriServ.do?uri=OJ:C:2010:135:0012:0014:EN:PDF (accessed on 13 May 2019).

European Commission. 2012. Language Competences for Employability, Mobility and Growth. Available online: https:/eur-lex.europa.eu/legal-content/EN/TXT/PDF/?uri=CELEX:52012SC0372\&from=NL (accessed on 13 May 2019).

European Commission. 2013. European Higher Education in the World. Available online: http://ec.europa.eu/ transparency/regdoc/rep/1/2013/EN/1-2013-499-EN-F1-1.Pdf (accessed on 13 May 2019).

Ferguson, Gibson. 2010. English in Language Policy and Management. In The Cambridge Handbook of Language Policy. Edited by Bernard Spolsky. Cambridge: Cambridge University Press, pp. 475-98.

Fortanet-Gómez, Inmaculada. 2012. Academics' Beliefs about Language Use and Proficiency in Spanish Multilingual Higher Education. AILA Review 25: 48-63. [CrossRef]

Hultgren, Anna Kristina. 2014. Whose Parallellingualism? Overt and Covert Ideologies in Danish University Language Policies. Multilingua 33: 61-87. [CrossRef]

Maringe, Felix, and Nicholas Foskett. 2010. Globalization and Internationalization in Higher Education: Theoretical, Strategic and Management Perspectives. New York: Continuum International Pub. Group.

MECD (Ministerio de Educación, Cultura y Deporte, and España Gobierno de). $2014 . \quad$ Estrategia para la Internacionalización de las Universidades Españolas 2015-2020. Available online: http: //www.educacionyfp.gob.es/educacion-mecd/dms/mecd/educacion-mecd/areas-educacion/universidades/ politica-internacional/estrategia-internacionalizacion/EstrategiaInternacionalizaci-n-Final.pdf (accessed on 13 May 2019).

Pérez-Llantada, Carmen. 2018. Bringing into Focus Multilingual Realities: Faculty Perceptions of Academic Languages on Campus. Lingua 212: 30-43. [CrossRef]

SEPIE. 2017. Internationalisation of Higher Education in Spain: Reflections and Perspectives. Edited by Adriana Pérez-Encinas, Laura Howard, Laura E. Rumbley and Hans De Wit. Madrid: Spanish Service for the Internationalisation of Education.

Soler-Carbonell, Josep, and Hakan Karaoglu. 2015. English as an Academic Lingua Franca in Estonia: Students' Attitudes and Ideologies. In Attitudes towards English in Europe. Edited by Andrew Linn, Neil Bermel and Gibson Ferguson. Berlin: DE GRUYTER, vol. 1, chp. 9. pp. 213-38. [CrossRef] 
Spolsky, Bernard. 2012. The Cambridge Handbook of Language Policy. Cambridge: Cambridge University Press. Wächter, Bernd, and Friedhelm Maiworm. 2014. English-Taught Programmes in European Higher Education: The State of Play in 2014. Bonn: Lemmens.

(C) 2019 by the author. Licensee MDPI, Basel, Switzerland. This article is an open access article distributed under the terms and conditions of the Creative Commons Attribution (CC BY) license (http://creativecommons.org/licenses/by/4.0/). 